\title{
FEATURES OF FORMATION OF PSYCHOLOGICAL READINESS OF ATHLETES IN SHOOTING FOR COMPETITIVE ACTIVITY
}

\begin{abstract}
In modern pedagogical science, the technology of solving educational problems is a necessary condition for the effective organization of the learning process, since it fully presents the methodological and organizational features of achieving the formulated educational goal. To solve the problems of psychological preparation for competitive activity, a special system of preparatory measures is used, aimed at teaching methods of self-regulation of mental states and special skills to act in competition. The use of these techniques ensures the achievement of the goal of creating a state of combat readiness in an athlete immediately before participating in a competition. The simulated competitive obstacles and difficulties must be adequate to the athlete's psychological readiness to overcome them. The successful application of modeling in training presupposes a preliminary study of the content of obstacles, the individual originality of the difficulties caused by them in each specific athlete and the determination of effective ways to overcome them on this basis. The tasks of psychological preparation of a shooter to overcome obstacles unexpectedly arising during the competition should be solved on the basis of training the stability of the nervous system to bad and good shots, to unfavorable conditions of competitive activity. As a means of psychological preparation of athletes to overcome the surprises of competitive wrestling, it is proposed to perform competitive exercises: at the maximum volitional and physical efforts; in any weather; without the help of a coach; in a state of fatigue; with the complication of situations of activity. When solving this problem, combine the methods of persuasion and explanation with the methods of practical exercise, apply the competitive method and conduct training sessions with the modeling of certain competitive obstacles. It is proposed to carry out the formation of psychological readiness to overcome competitive obstacles and difficulties through the mental and practical solution of specially developed intellectual problems, in theoretical and practical lessons. In practical exercises, it is recommended to use the exercise method in order to form skills and abilities to overcome competitive difficulties.

Key words: pedagogy of sports, psychology of sports, cultural training, psychological training, education, readiness for mental performance, training for mental performance, theory of training for athletes.
\end{abstract}

In modern pedagogical science, the technology of solving educational problems is a necessary condition for the effective organization of the learning process, since it fully presents the methodological and organizational features of achieving the formulated educational goal.

To solve the problems of psychological preparation for competitive activity, a special system of preparatory measures is used, aimed at teaching methods of self-regulation of mental states and special skills to act in competition. The use of these techniques ensures the achievement of the goal of creating a state of combat readiness in an athlete immediately before participating in a competition.

One of the most important conditions in the formation of shooting skills is psychological training. It pays great attention to the education of the ability to intentionally regulate emotional states, including during competitions.

The purpose of the article is to consider the peculiarities of the formation of psychological readiness of athletes in shooting for competitive activity.

As the readiness of the shooter changes, the direction, content and methods of psychological training change. Psychological training forms the specific qualities needed to reach the top of mastery, often becomes an independent, main direction. The human psyche has its own state, the stability of which is ensured by conscious purposefulness and through some unconscious mechanisms. And for the shooter it is extremely important to learn to control your body to monitor your actions in stressful competitive situations and show decent results. It is equally important for the athlete to know the techniques aimed at restoring performance after strenuous exercise.

The development of appropriate psychological methods in this area is timely and relevant. There are obvious significant differences in the perception of mental stress depending on whether the shooting takes place in training or competitive activities. One of the most important conditions in the formation of skills in bullet shooting is psychological training. It pays great attention to the education of the ability to intentionally regulate emotional states, including during competitions. In the second case, there is inevitably increased emotional arousal, a sense of responsibility for the result of shooting, increasing concentration and demands on their actions, so it is especially important for the shooter to learn in a competitive environment to maintain composure, calm and self-confidence.

The methodological development of the theory of training athletes to overcome unexpected obstacles and difficulties in sports activity received in the works of the outstanding scientist A. Ts. Puni. In his writings, he notes that the special formation of a state of psychological readiness for competition is a process of directed organization of the athlete's consciousness and actions, based on the expected conditions of the future competition. According to the author, the directed organization of the athlete's consciousness is to create an adequate reflection of the expected conditions of the upcoming competition, correlate it with the reflection of the athlete's own capabilities in achieving success and, on this basis, cause an appropriate fighting attitude to performance in the competition.

The system of links in the psychological preparation of athletes for the competition is determined by solving the following problems. 
1. Gathering information about the conditions of the upcoming competition and the characteristics of the enemy.

2. Clarification of information about the fitness level, capabilities of an athlete or team, as well as the prospects for their change by the beginning of the competition.

3. Determination and formulation of the purpose of participation in the competition.

4. Formation and actualization of socially significant motives for performing in the competition.

5. Probabilistic programming of competitive activity (performed in the course of mental and practical actions with modeling the conditions of the upcoming competition and is aimed at determining the tactical plan of activity).

6. Special preparation for meeting competitive obstacles of varying degrees of difficulty (especially unexpected) and exercise in overcoming them.

7. Providing techniques for self-regulation of possible unfavorable internal states.

8. Selection and use of methods of preserving neuropsychological freshness by the beginning of the competition, its restoration during the competition.

As we can see, a certain place in special psychological training is occupied by training athletes to overcome obstacles and difficulties that unexpectedly arise during competitive wrestling.

A. Ts. Puni [6] believes that preparation for a meeting with competitive obstacles is associated with purposeful organization and implementation of the method of modeling possible obstacles in the training process.

This teaching method is defined as mentally rehearsing future actions in anticipated conditions. Such playing is carried out in a chain of mental actions, which are in the nature of a mental experiment. Moreover, mental execution of actions is ideomotor training. Acting in the mind, the athlete always imagines his movements. Such representations are based on the revitalization of various temporary connections in the cerebral cortex. The external effect is manifested in motor, autonomic and other reactions, which fully correspond to the reactions arising from the practical performance of an imaginary action.

Modeling activity greatly expands the possibilities of cognition. With the help of modeling, an additional opportunity is created to obtain a complete characteristic of not only the object of knowledge, but also a rational response.

The following types of models are widely used in sports: 1) physical material; 2) real-mathematical; 3) logicalmathematical.

The first type includes models that have a physical, chemical or biological nature, similar to the nature of the studied phenomenon and retaining a geometric similarity to the original. They differ from the original only in size, in the rate of flow of the phenomenon under study.

The second type includes models that differ from the prototype in physical, chemical or biological nature. The same mathematical description as the original is allowed. Such models include: a) models of requirements for an ideal athlete; b) modeling of competitive conditions; c) the use of technical teaching aids in training; d) development of new schemes for planning the educational and training process. The third type includes models that are constructed from signs. In them, the physical, chemical or biological characteristics of the prototype and model no longer play any role. Only logical and mathematical properties matter here. These are abstract models. For example, the model of the growth of sports results, the level of training, the degree of reliability of the athlete's competitive activity.

The simulated competitive difficulties should be feasible, adequate to the level of the athlete's psychological readiness to overcome them. Only in this case they become a positive factor contributing to the formation of an athlete's volitional qualities.

Proceeding from the fact that in sport there is a wide range of possible competitive surprises, A. Ts. Puni recommends to systematically accumulate and systematize information about obstacles and difficulties of a competitive nature, which are inherent in the objective and subjective conditions of this sport.

H. G. Ozolyn [4] divides the methods and means of psychological preparation of athletes to overcome the surprises of competitive wrestling into two groups.

1. Methods of upbringing volitional qualities, including: a) fulfillment of the main competitive exercise in difficult conditions; b) conducting training sessions in any weather, if there is an opportunity to perform a competitive exercise; c) participation in competitions without any assistance from the coach.

2. Methods of analytical and integral training, including: a) exercises aimed at working out the elements of an athlete's readiness to overcome competitive surprises; b) complex exercises aimed at practicing competitive actions, subject to the active use of the athlete's mental, physical and other capabilities.

When forming psychological readiness to overcome difficulties in competitive activity, we suggest combining methods of persuasion and explanation with methods of practical exercise. At the same time, theoretical training is needed so that the athlete knows how he should act in such competitive situations. Practical training is essential to transform this knowledge into skills. We are talking about conducting special lectures and conversations with athletes about the essence of competitive surprises and possible ways to rationally overcome the difficulties that arise in this case.

The tasks of psychological preparation of a shooter to overcome obstacles unexpectedly arising during the competition should be solved on the basis of training the stability of the nervous system to bad and good shots, to unfavorable conditions of competitive activity. The author attaches great importance to the athlete's mastery of a strong skill of repeatedly executing shots with the maximum hit in the top ten. 
M. A. Ytkys [3] speaks about the necessity of modeling a competitive environment in training and performing training exercises in extreme conditions. At the same time, the shooter must take an active part in the planning and selection of these exercises, accurately imagine the meaning of each exercise, and agree with the need to perform them. The author offers an original way to solve the problem of training shooters to overcome competitive surprises - the method of ascertaining elements. This method is based on the temporary introduction of elements opposite to their content into the actions, behavior and state of an athlete. For example, when the weapon vibrates, it is recommended to swing it even more, for poor execution of a shot - a smile, for excitement:

- try to worry even more. The main goal of artificially creating contradictions is to prepare the shooter to successfully overcome competitive difficulties, to form the athlete's stress resistance even to obstacles that were not previously known to him and met for the first time during the competition.

M. A. Ytkys believes that when using the method of ascertaining elements, the effect of renewal appears in a paradoxical way, a surge of strength, an aggravation of perception, and the state of the shooter normalizes. Along with this, the author recommends using the following methodological techniques:

- changing the sequence of the exercise in conditions training contrary to competition rules;

- shooting after vestibular loading;

- shooting in a strong crosswind;

- doing exercises in distracting conditions;

- control shooting according to the rules of the competition.

According to V. N. Platonov [5], the most effective method for solving the problem of forming psychological readiness to overcome competitive obstacles and difficulties is the competitive method. To create these conditions, the author proposes to conduct training sessions with the modeling of certain competitive obstacles.

E. N. Hohunov [2] proposes to use intellectual tasks specially developed by a trainer or psychologist when forming athletes' psychological readiness to overcome competitive difficulties. The results of his research showed the low effectiveness of traditional lectures and conversations in the work with athletes. As the author notes, such theoretical studies lead to a greater extent to the expansion and deepening of the athlete's knowledge, the formation of his own attitude to extreme situations of a competitive nature and has little effect on the development of his intellectual abilities associated with the search for a rational way to successfully overcome difficulties that unexpectedly arise in the process competitive activity.

The formation of the psychological readiness of athletes to overcome competitive difficulties with the use of intellectual tasks is proposed to be realized through the organization of theoretical and practical lessons.

The theoretical lessons are carried out: 1) modeling of extreme situations in intellectual tasks; 2) modeling of rational ways to overcome extreme situations in solving intellectual problems.

Practical lessons include: 1) modeling of extreme situations in conditions of practical fulfillment of training activities (competitive method); 2) control activities related to models of extreme situations for practical training and models to determine the level of psychological readiness of an athlete to overcome competitive obstacles and difficulties.

In modern pedagogy, it is generally accepted that the exercise method is the most effective among practical methods [1].

Exercise is a teaching method that is a systematic, organized repetition of actions in order to master them or improve their quality. The main advantage of this method is that it provides effective formation of skills and abilities. To practice something means to master, strengthen and repeat some practical action.

Thus, the formation of a state of psychological readiness for competition is a process of directed organization of the athlete's consciousness and actions, based on the expected conditions of the future competition.

Modeled competitive obstacles and difficulties must be adequate to the athlete's psychological readiness to overcome them. The successful application of modeling in training presupposes a preliminary study of the content of obstacles, the individual originality of the difficulties caused by them in each specific athlete and the determination of effective ways to overcome them on this basis.

As a means of psychological preparation of athletes to overcome the surprises of competitive wrestling, it is proposed to perform competitive exercises: at the maximum volitional and physical efforts; in any weather; without the help of a coach; in a state of fatigue; with the complication of situations of activity. When solving this problem, combine the methods of persuasion and explanation with the methods of practical exercise, apply the competitive method and conduct training sessions with modeling of certain competitive obstacles. It is proposed to carry out the formation of psychological readiness to overcome competitive obstacles and difficulties through the mental and practical solution of specially developed intellectual problems, in theoretical and practical lessons. In practical exercises, it is recommended to use the exercise method in order to form skills and abilities to overcome competitive difficulties.

\section{Bibliography:}

1. Акимова Л. Н. Психология спорта : курс лекций. Одесса : Негоциант, 2004. 127 с.

2. Гогунов Е. Н., Мартьянов Б. И. Психология физического воспитания и спорта : учебное пособие для студ. высш. пед. учеб, заведений. Москва : Академия, 2004. 288 с. 
3. Иткис М. А. Специальная подготовка стрелка-спортсмена. Москва : ДОСААФ, 1982. 128 с.

4. Озолин Н. Г. Современная система спортивной тренировки. Москва : Физкультура и спорт, 1970. 479 с.

5. Платонов В. Н. Система подготовки спортсменов в Олимпийском спорте. Москва : Советский спорт, 2004.800 с.

6. Пуни А. Ц. Психологическая подготовка к соревнованию. Москва : Физкультура и спорт, 1969. 88 с.

\section{References:}

1. Akymova L. N. (2004) Psykholohyia sporta: kurs lektsyi [Sports psychology: a course of lectures]. Odesa: Nehotsyant. [in Russian]

2. Hohunov E. N., Martianov B. Y. (2004) Psykholohyia fyzycheskoho vospytanyia y sporta: uchebnoe posobye dlia stud. vyssh. ped. ucheb, zavedenyi. [Psychology of physical education and sport: a textbook for students. higher. ped. study, institutions]. Moscow: Akademyia. [in Russian]

3. Ytkys M. A. (1982) Spetsyalnaia podhotovka strelka-sportsmena [Special training of an athlete shooter]. Moscow: DOSAAF. [in Russian]

4. Ozolyn N. H. (1970) Sovremennaia systema sportyvnoi trenyrovky [Modern sports training system]. Moscow: Fyzkultura y sport. [in Russian]

5. Platonov V. N. (2004) Systema podhotovky sportsmenov v Olympyiskom sporte [The system of training athletes in Olympic sports]. Moscow: Sovetskyi sport. [in Russian]

6. Puny A. Ts. (1969) Psykholohycheskaia podhotovka k sorevnovanyiu [Psychological preparation for the competition]. Moscow: Fyzkultura y sport. [in Russian]

Дмітрієва Н. С. Особливості формування психологічної готовності спортсменів із кульової стрільби до змагальної діяльності

У сучасній педагогічній науці технологія розв'язання освітніх завдань є необхідною умовою ефективної організачії прочесу навчання, оскільки в ній повною мірою представлено методичні та організаційні особливості досягнення сформульованої навчальної мети. Для розв'язання завдань психологічної підготовки до змагальної діяльності застосовується спечіальна система підготовчих заходів, спрямованих на навчання прийомів саморегуляиії психічни станів і спеціальних умінь діяти в умовах змагання. Застосування цих прийомів забезпечуе досягнення мети створення у спортсмена стану бойової готовності безпосередньо перед участю в змаганні. Модельовані змагальні перешкоди і трудноші повинні бути адекватними психологічній готовності спортсмена до їх подолання. Успішне застосування моделювання в навчанні передбачає попереднє вивчення змісту перешкод, індивідуальної своєрідності викликаних ними труднощів у кожного конкретного спортсмена й визначення на иій основі ефективних способів їх подолання. Завдання психологічної підготовки стрільия до подолання несподівано виниклих під час змагання перешкод повинні розв'язуватися на основі тренування стійкості нервової системи до поганих і добрих пострілів, несприятливих умов змагальної діяльності. Як засоби психологічної підготовки спортсменів до подолання несподіванок змагальної боротьби пропонується виконувати змагальні вправи: на максимумі вольових і фізичних зусиль; за будь-якої погоди; без допомоги з боку тренера; у стані стомлення; під час ускладнення ситуачій діяльності. Під час розв'язання иього завдання поєднувати методи переконання й роз'яснення з методами практичної вправи, застосовувати змагальний метод і проводити тренувальні заняття з моделюванням певних змагальних перешкод. Пропонується здійснювати формування психологічної готовності до подолання змагальних перешкод $і$ труднощів через розумове й практичне рішення спеціально розроблених інтелектуальних завдань на теоретичних і практичних заняттях. На практичних заняттях для формування вмінь і навичок подолання змагальних труднощів рекомендується застосовувати метод вправи.

Ключові слова: педагогіка спорту, психологія спорту, кульова стрільба, психологічна підготовка, змагання, готовність до змагальної діяльності, підготовка до змагальної діяльності, теорія підготовки спортсменів. 